\title{
A Malignant Lymphoma Growing Inside a Cardiac Mixoma: A Case Report
}

\author{
Sergio Pirola ${ }^{1 *}$, MD; Stefano Fiori ${ }^{2}$, MD; Fausto Maffini ${ }^{3}$, MD; Giulia Mostardini ${ }^{1}, \mathrm{RT}$; Giorgio Mastroiacovo ${ }^{1,4^{*}}$, MD;
} Gianluca Polvani ${ }^{1,4}, \mathrm{MD}$

DOI: $10.21470 / 1678-9741-2021-0081$

\begin{abstract}
Introduction: Lymphomas arising from cardiac myxomas represent a particularly rare pathology, with only few cases reported in the literature.

Case presentation: We report a complete excision of a malignant lymphoma arising from a cardiac myxoma in a 44-year-old female patient. The myxoma presented like a floating mass within the left atrium with
\end{abstract}

a maximum diameter of $3.5 \mathrm{~cm}$. The clinical post-operative period was uneventful and the patient was dismissed on the $6^{\text {th }}$ post-operative day.

Conclusion: This case reinforces the concept of radical excision of cardiac neoplasms.

Keywords: Myxoma. Lymphoma Heart Neoplasms. Epstein-Barr Virus. Postoperative Period.

\begin{tabular}{ll}
\hline Abbreviations, acronyms \& symbols \\
\hline CCS & $=$ Canadian Cardiovascular Society \\
CT & $=$ Computed tomography \\
DLBCL-NOS & $=$ Large B-cell lymphoma not otherwise specified \\
EBV & $=$ Epstein-Barr virus \\
EBER & $=$ Epstein-Barr virus-encoded small RNAs \\
FA-DLBCL & $=$ Fibrin-associated diffuse large B-cell lymphoma \\
LMP1 & $=$ Latent membrane protein 1 \\
NYHA & $=$ New York Heart Association \\
\hline
\end{tabular}

\section{INTRODUCTION}

Cardiac myxomas account for the majority of cardiac tumours (50\%) and mainly affect middle-aged women ${ }^{[1]}$. Primary cardiac lymphoma is a very rare neoplasm that accounts for $2 \%$ of all primary cardiac tumours ${ }^{[2]}$. Lymphomas growing in the context of cardiac myxomas are extremely rare mixed tumours, with just few cases reported in literature.

\section{Case Presentation}

A previously healthy 44-year-old female patient presented to our hospital from an outpatient cardiology clinic with an echocardiographic finding of a floating mass within the left atrium.

'Department of Cardiac Surgery, Centro Cardiologico Monzino, IRCCS, Milan, Italy. 2Division of Diagnostic Haematopathology, European Institute of Oncology, IRCCS, Milan, Italy.

${ }^{3}$ Division of Pathology, European Institute of Oncology IRCCS, Milan, Italy.

${ }^{4}$ Department of Cardiovascular Sciences and Community Health, University of Milan, Italy.

*These authors equally contributed to this manuscript
She was symptomatic for a few months for asthenia, dyspnoea and dizziness. She denied lipothymia or syncope and any history of drug/alcohol abuse or recent travel. Her family history was negative for cardiovascular/neoplastic diseases.

The patient was in good clinical condition, NYHA class I and CCS 0. Cardiac auscultation revealed a classical diastolic "tumour plop", not accompanied by another significant murmur.

An urgent transthoracic echocardiogram with 3D digital reconstruction of the images was performed and confirmed the primary diagnosis (Figure 1). The mass originated from the fossa ovalis on the left side of the interatrial septum.

The maximum diameter was $3.5 \times 3 \mathrm{~cm}$. The mass had a lobulated, polypoid architecture and a narrow implantation stalk, appearing to be unstable, and prolapsed across the mitral valve orifice during diastole.

To complete the diagnostic framework, cardiac, lung and brain computed tomography (CT) scans (Figure 2) were performed, without any pathological findings and recent cardioembolic events were also excluded.

The patient was then scheduled for surgery. The operation was performed trough a left atriotomy. The tumour presented as a pale pink, grape-like, semi-transparent mass. It had a particularly gelatinous and friable consistency, with a high risk of fragmentation during surgical manipulation. Due to these atypical characteristics, we suspect the malignant nature of the neoplasm.

Correspondence Address:

\section{Sergio Pirola}

(iD) https://orcid.org/0000-0002-4573-8346

IRCCS Centro Cardiologico Monzino, street Parea 4, Milan, Italy - Zip code: 20138 E-mail: sergio.pirola@ccfm.it

Article received on February $7^{\text {th }}, 2021$ Article accepted on February $22^{\text {nd }}, 2021$. 
To perform a cautious removal of the mass, we started resecting it $2 \mathrm{~mm}$ from the implant base using a No. 11 scalpel blade to reduce the risk of tumour fragmentation.

The next step was to perform a radical fullthickness resection of the implant base, located in the atrial septum, leaving a safety margin of 5 millimetres. This was followed by repeated and extended washing of the left chambers of the heart to reduce the risk of embolization of the remaining tumour fragments. The redundant interatrial septum, though largely resected, was closed by a direct suture. No complications occurred in the postoperative period, and the patient was discharged on the $6^{\text {th }}$ post-operative day to a rehabilitation facility.

At gross examination, surgical specimens included: a lesion with dimensions of $3.5 \times 3 \mathrm{~cm}$, pedunculated, translucid and with a villous surface, focally covered by fibrinous exudate; a $1.5 \mathrm{~cm}$ implantation stalk and a fragment of interatrial septum.

Histological analysis showed that the lesion consisted of myxoid matrix containing thin vessels and scattered stellate cells, without mitotic activity and cytologic atypia. Interestingly, the fibrinous layer focally covering the lesion contained few dense aggregates consisting of large, blastic lymphoid cells, with clear-cut atypical features (Figure 3).

On immunohistochemical staining, the stellate cells embedded in the myxoid matrix were positive for CD34 and negative for cytokeratins AE1/ AE3, CD31 and CD45/LCA, and with a very low Ki67 proliferation rate $(<2 \%)$. Such findings were consistent with cardiac myxoma.

Further immunohistochemical evaluation showed a B-cell phenotype (positive for CD20, PAX5, CD79A) of the atypical, blastic lymphoid cells, along with partial positivity for BCL6, IRF4, BCL2, CD30 and C-MYC ( $<40 \%$ of cells), negativity for CD10, CD5, CD15, ALKC and HHV8, and a very high Ki67 proliferation index (>80\%). In situ hybridization for Epstein-Barr virus (EBV/EBER) was diffusely positive (Figure 3).

Histological features and incidental findings were all consistent with an EBV-positive fibrin-associated large B-cell lymphoma, arising within a cardiac myxoma.

The implantation stalk was focally involved by myxoma, but free of lymphoma, suggesting complete resection of the lesion.

Total body CT scan and 18-FDG positron emission tomography excluded distant metastases. Oncologic consultation did not indicate adjuvant chemotherapy or radiotherapy.

\section{DISCUSSION}

Myxoma is the most common type of tumour among all primary cardiac neoplasms ${ }^{[1]}$. They usually

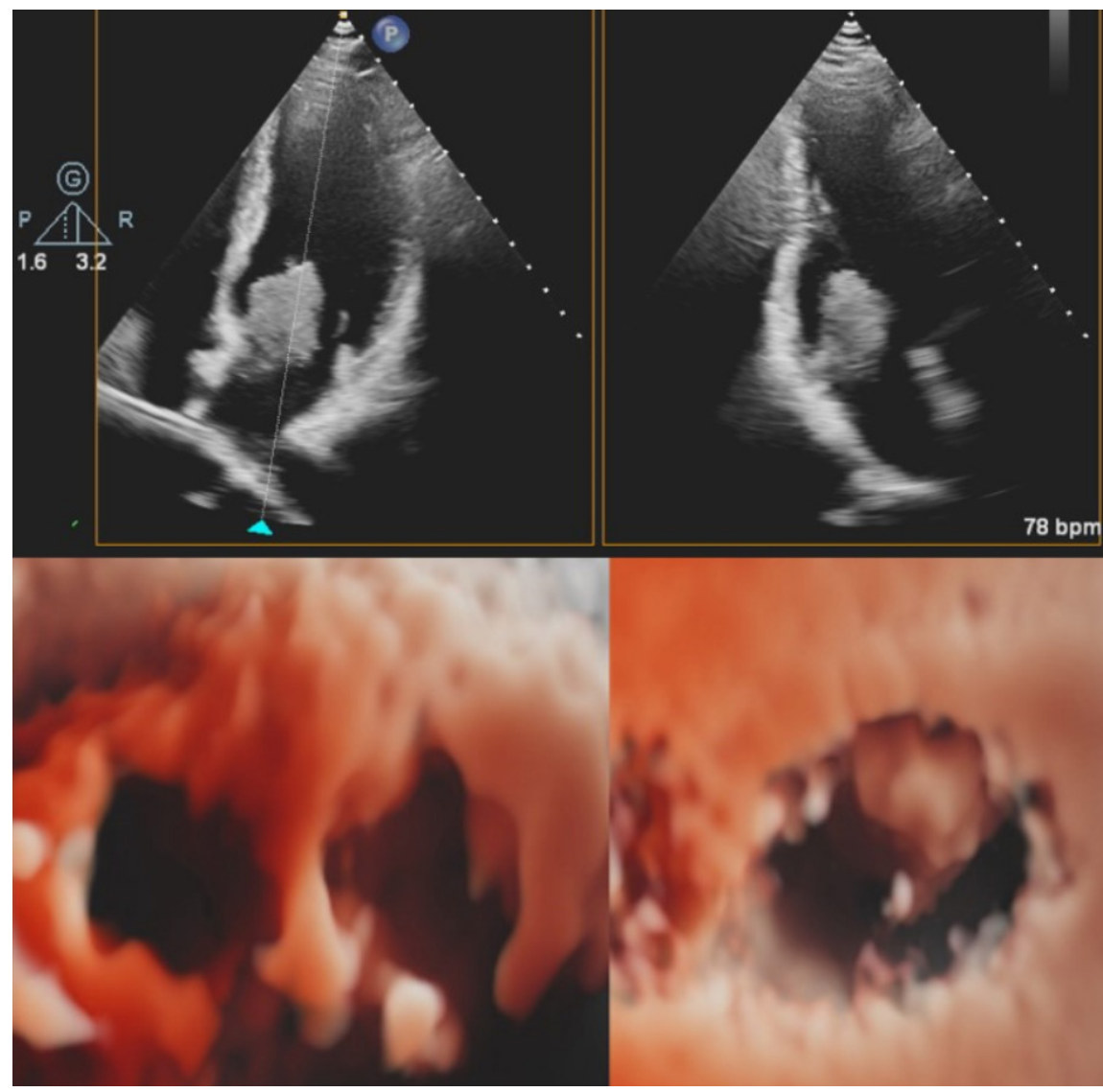

Fig. 1 - 2D transthorachic echocardiography images and 3D reconstruction of the left atrial mass.
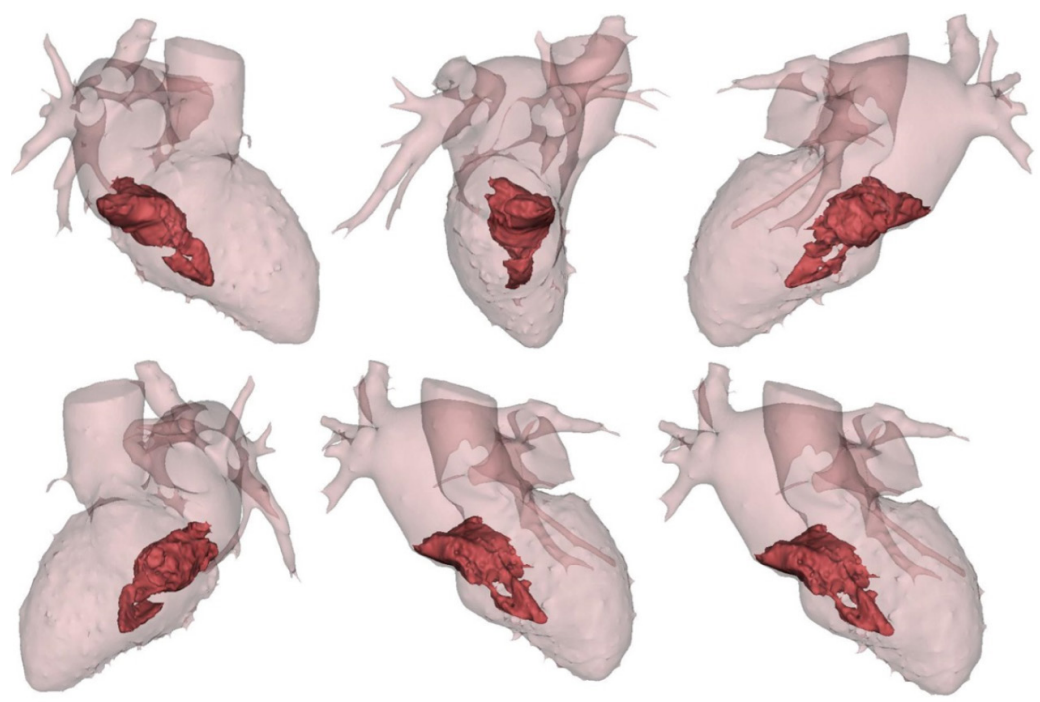

Fig. 2 - CT-based 3D virtual reconstruction of the mass performed using MIMICS software showing the extremely irregular borders and a narrow implantation stalk in the fossa ovalis. 


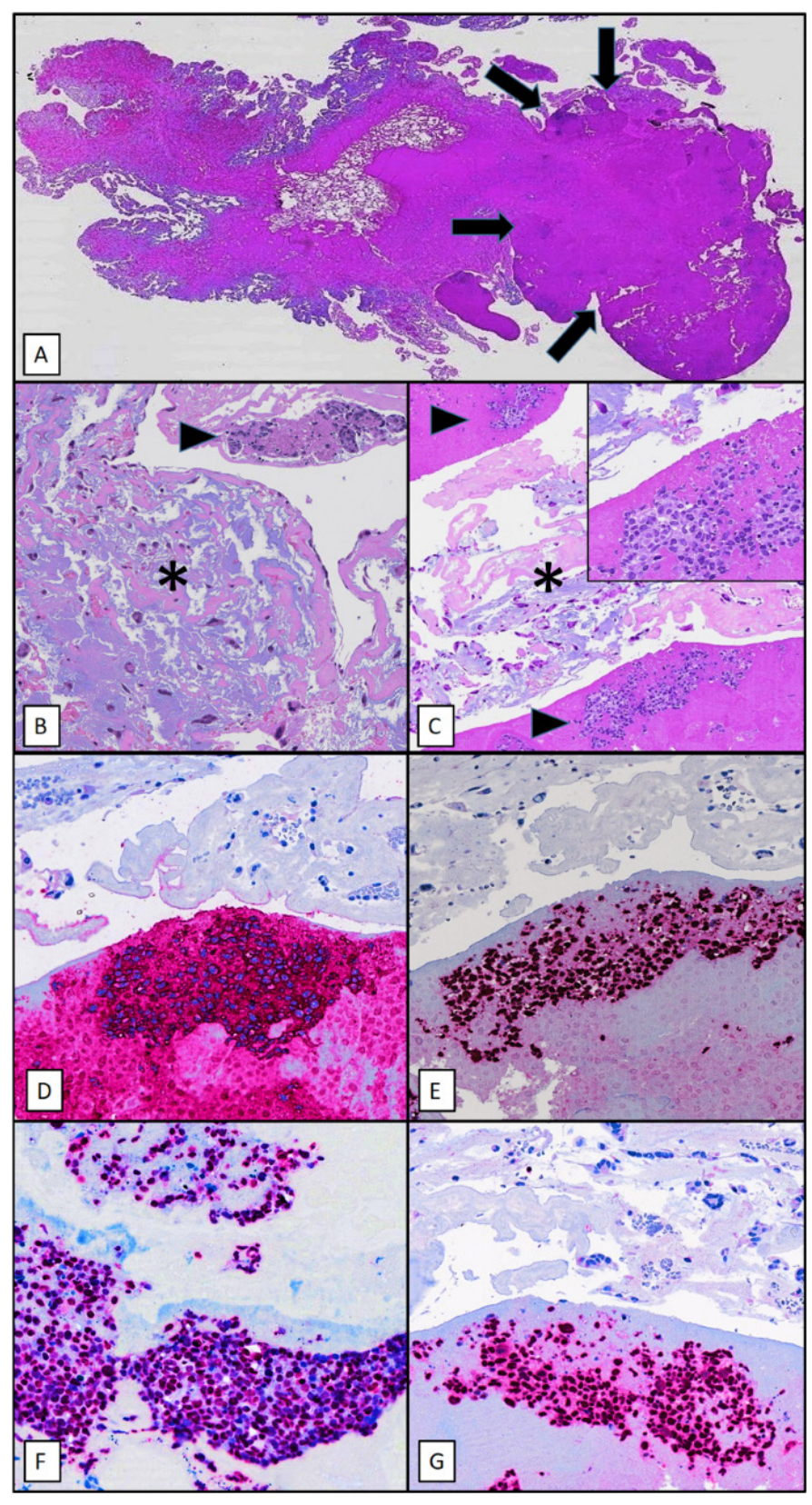

Fig. 3 - A, B, C: Morphological features of the lesion. Whole-mount section of myxoma, with villous surface and a superficial fibrinous cap (arrows) containing lymphoid aggregates (A, haematoxilineosin). The myxoma consists of a translucent loose matrix containing scattered stellate cells (asterisk). The lymphoid cells embedded in fibrinous material (arrowhead) are large-sized and atypical (B, C, inset, haematoxilin-eosin). $D, E, F$ : Immunophenotypic features of fibrinassociated diffuse large B-cell lymphoma. The atypical lymphoid cells have a B-cell phenotype, being positive for CD20 (A) and PAX5 (B), are diffusely positive for EBV/EBER (C) and have a high Ki67 proliferation index (D), in contrast to the myxoma cells (D, upper half), which are almost completely originate from the fossa ovalis with a growth directed towards the left atrial cavity ${ }^{[3]}$. Common symptoms are related to embolic events due to myxoma fragments embolization and syncope episodes due to diastolic mitral valve obstruction ${ }^{[1]}$.

Cardiac lymphomas are instead rare, amounting to only $0.6 \%$ of all cardiac tumours ${ }^{[4]}$. Although several subtypes of lymphomas may arise in the heart, the most common is diffuse large B-cell lymphoma not otherwise specified (DLBCL-NOS), usually associated with an aggressive biological behaviour ${ }^{[5-7]}$. On the other hand, the most frequent lymphoproliferative disease associated with cardiac myxoma is fibrin-associated diffuse large B-cell lymphoma (FA-DLBCL), with 16 cases reported so far ${ }^{[8]}$.

FA-DLBCL is a recently recognized entity ${ }^{[9]}$, included within the spectrum of diffuse large B-cell lymphomas associated with chronic inflammation and has highly distinctive features: it arises in fibrinous material covering or contained in sites of chronic inflammation (most commonly within the cardiovascular system), neither forming a mass nor producing specific symptoms ${ }^{[9,10]}$. Typically, the diagnosis is incidental, during histologic examination. FA-DLBCL is invariably EBV-positive.

It is therefore likely that most of the previously reported cases of lymphomas arising in association with cardiac myxomas would be re-classified to FA-DLBCL according to the current classification of the World Health Organization, due to the concomitant ${ }^{[9]}$ positivity for EBV ${ }^{[10-17]}$ and for the typical location within the fibrinous material covering the myxoma ${ }^{[18,19]}$.

More importantly, despite aggressive histological features (large cell morphology, high proliferation rate), FA-DLBCL is a localized disease with an indolent behaviour and a favourable outcome even with surgical excision alone. The rare event of relapse and the associated risk of local invasion ${ }^{[3,9,20]}$, however, reinforce the need for a complete surgical excision.

\section{CONCLUSION}

Our case report suggests that cardiac surgeons must be aware that even apparently benign cardiac masses can conceal malignant lesions, adopting a presumptive attitude of "malignancy until proven otherwise", which should prompt always an accurate and radical excision of the mass.

Recognition of a macroscopic unusual aspect of the lesion is of paramount importance, as all reported cases of lymphoid proliferation arising within a cardiac myxoma showed a partial or global gelatinous aspect of the neoplasm (especially in its peripheral areas) (Table 1).

The rarity of this disorder is an obstacle to prospective studies. Endocavitary masses with the peculiar macroscopic characteristics we have described could indicate a high probability of lymphocytic infiltration in the context of myxomatous masses. In this case, a specific, integrated diagnostic and therapeutic pathway should be followed, including: wide and radical resection and possibly a bone marrow specimen (easily collected during surgery from the sternal bone), to ensure a fast staging if the lesion would be proven malignant. 
Table 1. Available literature data regarding cases of myxomas in which B-cell lymphomas were identified.

\begin{tabular}{|c|c|c|c|c|c|c|}
\hline First author & $\begin{array}{l}\text { Location and } \\
\text { size }\end{array}$ & Symptoms & Lymphoma & EBV type & Gross analysis & Follow-up \\
\hline Bagwan ${ }^{[17]}$ & $\begin{array}{l}\text { Left atrium } \\
(4 \times 2 \mathrm{~cm})\end{array}$ & Multiple strokes & $\begin{array}{l}\text { Diffuse large B-cell } \\
\text { lymphoma }\end{array}$ & Not available & $\begin{array}{l}\text { Gelatinous, grape- } \\
\text { like, friable }\end{array}$ & Not available \\
\hline Dimitrova $^{[18]}$ & $\begin{array}{l}\text { Left atrium } \\
(7.5 \times 4.5 \mathrm{~cm})\end{array}$ & Chest pain & $\begin{array}{l}\text { Diffuse large B-cell } \\
\text { lymphoma }\end{array}$ & Not available & $\begin{array}{l}\text { Partially fimbriated } \\
\text { surface, gelatinous } \\
\text { and necrotic parts }\end{array}$ & Not available \\
\hline Loong $^{[11]}$ & $\begin{array}{l}\text { Left atrium } \\
(6.5 \times 4 \mathrm{~cm})\end{array}$ & $\begin{array}{l}\text { Cardiogenic shock, } \\
\text { ischemic stroke }\end{array}$ & $\begin{array}{l}\text { Diffuse large B-cell } \\
\text { lymphoma }\end{array}$ & $\begin{array}{l}\text { Type III latency } \\
(\text { EBER+, LMP1+) }\end{array}$ & Not described & $\begin{array}{c}\text { Patient deceased for } \\
\text { chemotherapy complications } \\
\text { (neutropenia + pneumonia) } \\
\text { at } 5 \text { months }\end{array}$ \\
\hline Svec ${ }^{[12]}$ & $\begin{array}{l}\text { Left atrium } \\
(3.7 \times 1.5 \mathrm{~cm})\end{array}$ & Ischemic stroke & $\begin{array}{l}\text { Diffuse large B-cell } \\
\text { lymphoma }\end{array}$ & $\begin{array}{l}\text { Type III latency } \\
(\text { EBER }+, \text { LMP1+) } \\
\end{array}$ & Not described & $\begin{array}{c}\text { No evidence of disease at } 7 \\
\text { months }\end{array}$ \\
\hline Bartoloni $^{[13]}$ & $\begin{array}{l}\text { Left atrium } \\
(5.5 \times 4.5 \mathrm{~cm})\end{array}$ & $\begin{array}{c}\text { Fever and } \\
\text { progressive fatigue }\end{array}$ & $\begin{array}{l}\text { Atypical lymphoid } \\
\text { B-cell proliferation }\end{array}$ & $\begin{array}{l}\text { Type II latency } \\
(\text { EBER }+, \text { LMP1+) }\end{array}$ & $\begin{array}{l}\text { Glistening, villous } \\
\text { and gelatinous } \\
\text { surface }\end{array}$ & $\begin{array}{c}\text { No evidence of disease at } 72 \\
\text { months }\end{array}$ \\
\hline Tapan ${ }^{[15]}$ & $\begin{array}{l}\text { Left atrium } \\
(4.2 \times 3.6 \mathrm{~cm})\end{array}$ & Palpitations & $\begin{array}{l}\text { Diffuse large B-cell } \\
\text { lymphoma }\end{array}$ & $\begin{array}{l}\text { Type III latency } \\
(\text { EBER }+, \text { LMP1+) }\end{array}$ & Not described & $\begin{array}{c}\text { No evidence of disease at } 12 \\
\text { months }\end{array}$ \\
\hline Aguilar ${ }^{[14]}$ & $\begin{array}{l}\text { Left atrium } \\
(6 \times 2.5 \mathrm{~cm})\end{array}$ & $\begin{array}{c}\text { Transient ischemic } \\
\text { attack }\end{array}$ & $\begin{array}{l}\text { Diffuse large B-cell } \\
\text { lymphoma }\end{array}$ & $\begin{array}{l}\text { Type III latency } \\
(\text { EBER }+, \text { LMP1+) }\end{array}$ & Not described & $\begin{array}{c}\text { No evidence of disease at } 42 \\
\text { months }\end{array}$ \\
\hline Pineda $a^{[3]}$ & $\begin{array}{l}\text { Left atrium } \\
(6.5 \times 3 \mathrm{~cm})\end{array}$ & $\begin{array}{l}\text { Coronary } \\
\text { embolization }\end{array}$ & $\begin{array}{l}\text { Diffuse large B-cell } \\
\text { lymphoma }\end{array}$ & Not available & Reddish, gelatinous & Not available \\
\hline Park ${ }^{[20]}$ & $\begin{array}{l}\text { Left atrium } \\
(6 \times 3.2 \mathrm{~cm})\end{array}$ & $\begin{array}{l}\text { Peripheral arterial } \\
\text { embolization }\end{array}$ & $\begin{array}{l}\text { Diffuse large B-cell } \\
\text { lymphoma }\end{array}$ & $\begin{array}{l}\text { Type III latency, } \\
\text { EBER + }\end{array}$ & $\begin{array}{l}\text { Irregular surface, } \\
\text { friable }\end{array}$ & Not available \\
\hline Boyer ${ }^{[9]}$ & $\begin{array}{l}\text { Left atrium } \\
(? \mathrm{~cm})\end{array}$ & Syncope & $\begin{array}{l}\text { Diffuse large B-cell } \\
\text { lymphoma }\end{array}$ & EBER+ & Not available & $\begin{array}{l}\text { No evidence of disease at } \\
130 \text { months }\end{array}$ \\
\hline Boyer ${ }^{[9]}$ & $\begin{array}{l}\text { Left atrium } \\
\qquad(? \mathrm{~cm})\end{array}$ & $\begin{array}{l}\text { Syncope, cough, } \\
\text { dyspnoea }\end{array}$ & $\begin{array}{l}\text { Diffuse large B-cell } \\
\text { lymphoma }\end{array}$ & EBER+, LMP1+ & Reddish, gelatinous & $\begin{array}{l}\text { Patient died at } 2 \text { months for } \\
\text { cardiac cause }\end{array}$ \\
\hline Boyer ${ }^{[9]}$ & $\begin{array}{l}\text { Left atrium } \\
\qquad(? \mathrm{~cm})\end{array}$ & $\begin{array}{l}\text { Dyspnoea, } \\
\text { respiratory failure }\end{array}$ & $\begin{array}{l}\text { Diffuse large B-cell } \\
\text { lymphoma }\end{array}$ & EBER+, LMP1+ & Not available & $\begin{array}{c}\text { Recurrent FA-DLBCL at mitral } \\
\text { valve after } 25 \text { months. Patient } \\
\text { died at } 26 \text { months (embolic } \\
\text { stroke). }\end{array}$ \\
\hline $\operatorname{Yan}^{[10]}$ & $\begin{array}{l}\text { Left atrium } \\
\qquad(? \mathrm{~cm})\end{array}$ & $\begin{array}{l}\text { Congestive heart } \\
\text { failure }\end{array}$ & $\begin{array}{l}\text { Diffuse large B-cell } \\
\text { lymphoma }\end{array}$ & $\begin{array}{l}\text { Type III latency, } \\
\text { EBER+, LMP1+ }\end{array}$ & $\begin{array}{c}\text { Myxoid appearance } \\
\text { with an abundant } \\
\text { fibrinous or mucinous } \\
\text { background in the } \\
\text { centre }\end{array}$ & $\begin{array}{l}\text { No evidence of disease at } 7 \\
\text { months }\end{array}$ \\
\hline $\operatorname{Yan}^{[10]}$ & $\begin{array}{l}\text { Left atrium } \\
\qquad(? \mathrm{~cm})\end{array}$ & $\begin{array}{l}\text { Congestive heart } \\
\text { failure }\end{array}$ & $\begin{array}{l}\text { Diffuse large B-cell } \\
\text { lymphoma }\end{array}$ & $\begin{array}{l}\text { Type III latency, } \\
\text { EBER+, LMP1+ }\end{array}$ & $\begin{array}{l}\text { Myxoid appearance } \\
\text { with an abundant } \\
\text { fibrinous or mucinous } \\
\text { background in the } \\
\text { centre }\end{array}$ & $\begin{array}{c}\text { No evidence of disease at } 84 \\
\text { months }\end{array}$ \\
\hline $\operatorname{Yan}^{[10]}$ & $\begin{array}{l}\text { Left atrium } \\
\qquad(? \mathrm{~cm})\end{array}$ & $\begin{array}{l}\text { Congestive heart } \\
\text { failure }\end{array}$ & $\begin{array}{l}\text { Diffuse large B-cell } \\
\text { lymphoma }\end{array}$ & $\begin{array}{l}\text { Type III latency, } \\
\text { EBER+, LMP1+ }\end{array}$ & $\begin{array}{l}\text { Myxoid appearance } \\
\text { with an abundant } \\
\text { fibrinous or mucinous } \\
\text { background in the } \\
\text { centre }\end{array}$ & $\begin{array}{l}\text { No evidence of disease at } 3 \\
\text { months }\end{array}$ \\
\hline $\operatorname{Yan}^{[10]}$ & $\begin{array}{l}\text { Left atrium } \\
\qquad(? \mathrm{~cm})\end{array}$ & $\begin{array}{l}\text { Congestive heart } \\
\text { failure }\end{array}$ & $\begin{array}{l}\text { Diffuse large B-cell } \\
\text { lymphoma }\end{array}$ & $\begin{array}{l}\text { Type III latency, } \\
\text { EBER+, LMP1+ }\end{array}$ & $\begin{array}{c}\text { Myxoid appearance } \\
\text { with an abundant } \\
\text { fibrinous or mucinous } \\
\text { background in the } \\
\text { centre }\end{array}$ & $\begin{array}{l}\text { No evidence of disease at } \\
120 \text { months }\end{array}$ \\
\hline Present case & $\begin{array}{l}\text { Left atrium }(3.6 \\
\qquad \times 3 \mathrm{~cm})\end{array}$ & $\begin{array}{l}\text { Asthenia, dyspnoea } \\
\text { and dizziness }\end{array}$ & $\begin{array}{l}\text { Diffuse large B-cell } \\
\text { lymphoma }\end{array}$ & EBER+, LMP1+ & $\begin{array}{l}\text { Gelatinous, grape- } \\
\text { like, pale pink, } \\
\text { semi-transparent, } \\
\text { extremely friable }\end{array}$ & $\begin{array}{l}\text { No evidence of disease at } 4 \\
\text { months }\end{array}$ \\
\hline
\end{tabular}

EBER=Epstein-Barr virus-encoded small RNAs; LMP1=latent membrane protein 1 


\section{No financial support. \\ No conflict of interest.}

\section{Authors' roles \& responsibilities}

SP

Substantial contributions to the conception or design of the work; or the acquisition, analysis, or interpretation of data for the work; drafting the work or revising it critically for important intellectual content; final approval of the version to be published Histological analysis of the surgical specimen, curation of the anatomopathological part of the paper

FM Histological analysis of the surgical specimen, curation of the anatomopathological part of the paper.

GM Radiological image processing and reconstruction with special editing software (MIMICS, Materialise)

GM Collaboration in writing the paper and proofreading it, as well as editing the literature review

GP Coordination and supervision of the entire work of the team of researchers and final endorsement to the publication of the paper

\section{REFERENCES}

1. Bogaert J, Dymarkovski S, Taylor A, Muthurangu V. Clinical Cardiac MRI. 2nd edi. Berlin: Springer;2012.

2. Miguel CE, Bestetti RB. Primary cardiac lymphoma. Int J Cardiol. 2011;149(3):358-63. doi:10.1016/j.jicard.2010.02.016.

3. Pineda AM, Mihos CG, Nascimento FO, Santana O, Lamelas J, Beohar N. Coronary embolization from a left atrial myxoma containing malignant lymphoma cells. Tex Heart Inst J. 2015;42(6):565-8. doi:10.14503/THIJ14-4619.

4. Patel J, Sheppard MN. Pathological study of primary cardiac and pericardial tumours in a specialist UK centre: surgical and autopsy series. Cardiovasc Pathol. 2010;19(6):343-52.

5. Lam KY, Dickens P, Chan AC. Tumors of the heart. A 20-year experience with a review of 12,485 consecutive autopsies. Arch Pathol Lab Med. 1993;117(10):1027-31.

6. Bruce CJ. Cardiac tumours: diagnosis and management. Heart. 2011:97(2):151-60. doi:10.1136/hrt.2009.186320.

7. Petrich $\mathrm{A}$, Cho SI, Billett $\mathrm{H}$. Primary cardiac lymphoma: an analysis of presentation, treatment, and outcome patterns. Cancer. 2011;117(3):581-9.
8. Zanelli M, Zizzo M, Montanaro M, Gomes V, Martino G, De Marco L, et al. Fibrin-associated large B-cell lymphoma: first case report within a cerebral artery aneurysm and literature review. BMC Cancer. 2019;19(1):916. doi:10.1186/s12885-019-6123-1.

9. Boyer DF, McKelvie PA, de Leval L, Edlefsen KL, Ko YH, Aberman ZA, et al. Fibrin-associated EBV-positive large B-cell lymphoma: an indolent neoplasm with features distinct from diffuse large B-cell lymphoma associated with chronic inflammation. Am J Surg Pathol. 2017;41 (3):299312. doi:10.1097/PAS.0000000000000775.

10. Yan J, Luo D, Zhang F, He J, Yao S, Luo X, et al. Diffuse large B cell lymphoma associated with chronic inflammation arising within atrial myxoma: aggressive histological features but indolent clinical behaviour. Histopathology. 2017;71(6):951-9. doi:10.1111/his.13336.

11. Loong F, Chan AC, Ho BC, Chau YP, Lee HY, Cheuk W, et al. Diffuse large B-cell lymphoma associated with chronic inflammation as an incidental finding and new clinical scenarios. Mod Pathol. 2010;23(4):493-501. doi:10.1038/modpathol.2009.168.

12. Svec A, Rangaiah M, Giles M, Jaksa R, McAulay KA. EBV+ diffuse large B-cell lymphoma arising within atrial myxoma. An example of a distinct primary cardiac EBV+ DLBCL of immunocompetent patients. Pathol Res Pract. 2012;208(3):172-6.

13. Bartoloni G, Pucci A, Giorlandino A, Berretta M, Mignosa C, Italia F, et al. Incidental Epstein-Barr virus associated atypical lymphoid proliferation arising in a left atrial myxoma: a case of long survival without any postsurgical treatment and review of the literature. Cardiovasc Pathol. 2013;22(3):e5-10. doi:10.1016/j.carpath.2012.08.002.

14. Aguilar C, Beltran B, Quiñones P, Carbajal T, Vilcapaza J, Yabar A, et al. Large B-cell lymphoma arising in cardiac myxoma or intracardiac fibrinous mass: a localized lymphoma usually associated with Epstein-Barr virus? Cardiovasc Pathol. 2015;24(1):60-4. doi:10.1016/j.carpath.2014.08.007.

15. Tapan U, Pestana JB, Lee JC, Lerner A. Epstein-Barr virus-associated diffuse large B-cell lymphoma arising in atrial myxoma: a proposal for a modified therapeutic approach. Leuk Lymphoma. 2015;56(2):505-7. doi:10.3109/1 0428194.2014 .919632$.

16. Liu X, Liu P, Li J. EBV+ diffuse large B-cell lymphoma arising within atrial myxoma in Chinese immunocompetent patient. Int J Clin Exp Pathol. 2015;8(2):2159-64.

17. Bagwan IN, Desai S, Wotherspoon A, Sheppard MN. Unusual presentation of primary cardiac lymphoma. Interact Cardiovasc Thorac Surg. 2009:9(1):127-9. doi:10.1510/icvts.2009.204628.

18. Dimitrova KR, Hoffman DM, Geller CM, Thiagarjah P, Master J, Berger M, et al. Malignant B-cell lymphoma arising in a large, left atrial myxoma. Ann Thorac Surg. 2010;89(2):626-9. doi:10.1016/j.athoracsur.2009.06.096.

19. Kameda K, Shono T, Takagishi S, Kono S, Aoki T, Ito Y, et al. EpsteinBarr virus-positive diffuse large B-cell primary central nervous system lymphoma associated with organized chronic subdural hematoma: a case report and review of the literature. Pathol Int. 2015;65(3):138-43. doi:10.1111/pin.12242.

20. Park CK, Cho YA, Kim M, Shim HS. Malignant lymphoma arising in cardiac myxoma, presenting with peripheral arterial emboli. Cardiovasc Pathol. 2018;32:26-9. doi:10.1016/j.carpath.2017.10.001. 